УДК $803: 37: 681.3$

\title{
PEDAGOGICAL GRAMMAR AS THE FRAMEWORK OF TEFL RESEARCH. PART 5. NATIVE LANGUAGE MORPHOLOGY ACQUISITION AT THE SIMPLE SENTENCE STAGE
}

\section{Chernovaty L.M., Doctor of Sciences (Kharkiv)}

The paper presents the results of the experimental data analysis in the said sphere, as well as the list of the researched grammar morphemes. Basing upon a high degree of the data similarity, the author makes a conclusion that the native language morphology acquisition is a rule-governed process, which might be based upon the operation of language universals. Taking into account the said data, the author also offers assumptions concerning the existence of a universal sequence in the process of the grammar morphemes acquisition in English as a native language, as well as regarding the speed different allomorphsare acquired at. A particular morpheme may be acquired relatively quickly, while the fine-tuning of allomorph use microrules within the said general rule may require a relatively longer period. The author also offers the reason why some allomorphs are acquired faster in relation to natural words as compared to artificial ones. The paper summarises the characteristics, which may accelerate or slow down the process of grammar morphemes acquisition: perceptual saliency, frequency, semantic and grammar complexity. The latter is subdivided into further constituents: presence of redundancy or allomorphism and paradigm regularity. The author sums up the general principles of morphology acquisition in English as a native language, which amount to the following. Lexical acquisition means that paradigmatic variants are memorized as holistic units, and only later, their constituents are distributed among the corresponding categories. Generalisation is the result of subconscious formulation of a hypothetic rule related to the said variants use in speech. Overgeneralisation is viewed as a transfer of the specific rule to a wider range of objects than it actually applies to. Finally, uniqueness involves blocking the creation of the rules, allowing, for example, two plural forms of the same word. The author also outlines the prospects of his further research.

Key words: allomorph acquisition, morphology acquisition, native language acquisition, pedagogical grammar, uniqueness, universal grammar.

(C) Chernovaty L.M., 2018 
Черноватий Л.М. Педагогічна граматика як фреймове поняття для досліджень у галузі методики навчання іноземних мов. Частина 5. Засвосння морфології рідної мови на етапі простого речення. Наводяться результати аналізу досліджень у згаданій сфері, а також перелік досліджуваних граматичних морфем. Виходячи 3 високого ступеня подібності таких результатів, сформульовано висновок про те, що зміст засвоєння морфології рідної мови грунтується на певних правилах, а також про можливу роль мовних універсалій у цьому процесі. Виходячи 3 даних аналізу, запропоновано висновки про існування універсальної послідовності засвоєння граматичних морфем у процесі оволодіння англійською мовою як рідною, а також про різну швидкість засвоєння аломорфів однієї й тієї ж морфеми. Узагальнено характеристики, здатні прискорювати або сповільнювати процес засвоєння граматичних морфем, які включають перцептуальну опуклість, частотність, семантичну й граматичну складність. Узагальнено принципи засвоєння морфології англійської мови як рідної, до яких відносяться принципи лексичного засвоєння морфеми, генералізації, надгенералізаціі та одиничності. Окреслено перспективи подальшого дослідження 3 урахуванням отриманих результатів у процесі розробки педагогічної граматики іноземної мови.

Ключові слова: засвоєння аломорфів, засвоєння морфології, засвоєння рідної мови, педагогічна граматика, універсальна граматика.

Черноватый Л.Н. Педагогическая грамматика как фреймовое понятие для исследований в области методики обучения иностранных языков. Часть 5. Усвоение морфологии родного языка на этапе простого предложения. Приводятся результаты анализа экспериментальных данных в упомянутой сфере, а также перечень исследовавшихся грамматических морфем. Исходя из высокой степени сходства таких результатов, сформулирован вывод о правилосообразности процесса усвоения морфологии родного языка, а также о возможной роли языковых универсалий в этом процессе. Исходя из данных анализа, предложены также выводы о существовании универсальной последовательности усвоения грамматических морфем в процессе овладения английским языком как родным, а также о разной скорости усвоения алломорфов одной и той же морфемы. Обобщены характеристики, способные ускорять или замедлять процесс усвоения грамматических морфем, которые включают перцептуальную. выпуклость, частотность, семантическую и грамматическую сложность. Обобщены принципы усвоения морфологии английского языка как родного, к которым относятся принципы лексического усвоения, 
генерализации, сверхгенерализации и единичности. Очерчены перспективы дальнейшего исследования с учетом полученных результатов в процессе разработки педагогической грамматики иностранного языка.

Ключевые слова: педагогическая грамматика, универсальная грамматика, усвоение алломорфов, усвоение морфологии, усвоение родного языка.

Introduction to the series. Numerous research in teaching foreign languages, specifically in the development of grammar competence, often seem to lack a common framework to integrate them into a single area with uniform approaches, terminology and criteria. It accounts for the current importance of the issue under consideration.

The object of this paper is the comparative aspect of the native (NLA) and foreign languages acquisition (FLA) with the subject being the characteristics of the NLA. The aim of this study is to analyse the latter with the purpose of its further comparison with the FLA. This is the fifth (see [4-7]) in a series of articles focusing on the Pedagogical Grammar (PG) issue [9; 10], where the author, basing on the research data, is planning to discuss the various aspects of the problem.

As it was mentioned in the first article of the series [4], the development of an efficient PG should be based on an adequate FLA psycholinguistic model. Such PG has to take into account the regularities of the speech grammar mechanisms development in general and the foreign language grammar mechanisms in particular, specifically in the aspects where the NLA and FLA processes are different. In two previous papers $[6 ; 7]$, we compared several strategies, procedures and processes at the word-combination stage in the NLA, on the one hand, and in the FLA, on the other, which allowed to draw some conclusions. In this article, we are going to review the morphology acquisition at the simple sentence stage in NLA, which would be used for the comparison with the FLA in our next paper.

The simple sentence period in the NLA, which follows the first wordcombination period (see [6]), is believed to involve the acquisition of phonology, semantics and morphology (see [8]). The initial research focused on the so-called 'grammar morphemes' or 'functional words'. The list of the latter includes: (1) noun morphemes:(a) $-s$ (plural); (b) $-s$ (possessive case); 2) verb morphemes: (a) -ing (Continuous), (b) -s 
(Present Simple), (c) -ed (Past Simple), (d) -en (various morphemes to mark irregular forms of the Past Participle); 3) adjective morphemes: (a) -er (comparative degree), (b) -est (superlative degree); derivational morphemes of: (a) adverbs (-ly), (b) adjectives (-ful, -less, etc), (c) noun (-er, -ness, etc) and so on; 5) free morphemes: (a) not (verb negation), (b) modal verbs; (c) to (Infinitive); (d) personal pronouns; (e) other classes of pronouns (possessive, reflexive, demonstrative, relational), (f) articles, (g) -ing (Gerund), (h) -ing (Present Participle) and some others. Numerous experiments (see the review in [8-10]) proved that in grammar morphemes acquisition children develop a corresponding system of rules. The striking similarities of their acquisition patterns led to assume a certain role that language universals might be playing in this process.

A classic experiment, which proved that children develop their own rules and rely upon them in the subsequent communication, was conducted by J. Berko [2]. In this research, the experimenter checked the ability of children (4-5 years old) to mark the plural number of nouns with the appropriate allomorph $-s$, pronouncing it as [s] after voiceless consonants, as $[\mathrm{z}]$ - after vowels and voiced consonants, and as [əz] after [s], [z], [J], [t $f]$ ). To avoid the reproduction of the words, which the children might have heard before, the experimenter used artificially created words. For example, the subject was shown a card with a fictitious animal, which the experimenter called $a$ wug (This is a wug), and then showed a card with two animals of the same type, saying These are __ in an attempt to elicit the plural. The subject was expected to use the form [w/gz], i.e. to pronounce the ending as [z]. The same procedure was used to elicit the other variants of pronouncing the allomorph -sas [s] and [əz], using the fictitious animals of bik and gutch with the expected plural of [bıks] and [g $\left.\Lambda \mathrm{t} \int \partial \mathrm{z}\right]$ correspondingly. The subject successfully coped with the tasks, which allowed classifying the NLA process as a rule-governed behaviour.

The results of other research (see the review in [8]) - three variants of morpheme $-s$ (to mark the plural, possessive case and the third person in the Present Simple) with three allomorphs in each category - [s], [z] and [əz]; morpheme -ed (to mark the Past Simple with three allomorphs: [d], [t] and [əd]; morpheme -ing (the verb marker in the Present Continuous) - showed that the allomorph acquisition pace is not uniform. Single sound allomorphs are acquired faster, but the acquisition of [əz] 
and [əd] takes a little longer. Normally, the general rule is: a particular morpheme may be acquired relatively quickly, while the fine-tuning of allomorph use microrules within the said general rule may require a relatively longer period.

It is worth mentioning that in relation to natural words, children acquire the allomorphs [əz] and [əd] better than concerning artificial ones (e.g., gutches, bodded). It may happen because at the initial stage children acquire natural words (e.g., boxes) as holistic lexical units without splitting them into constituents. Only later, after a substantial amount of words has been stored in the child's memory, the subconscious generalization of the appropriate rule takes place. Other examples of this procedure, which is sometimes called the 'lexical principle of grammar acquisition', are provided further.

The analyses of data from a number of other research (J.de Villiers and P.de Villiers, R. Brown alone [3] and in cooperation with C. Hanlon, C. Fraser and U. Bellugi - see the review in [8]), gives enough ground to assume that there might be a universal sequence of grammar morpheme acquisition in the case of English as a native language. This sequence, in its turn, may be regarded as evidence in favour of language universals underlying the said sequence.

There have been attempts to establish characteristics, which may accelerate or slow down the process of grammar morphemes acquisition, thus affecting the position of a particular morpheme in the sequence. For example, R. Brown [3] suggested the following qualities of grammar forms that may have an impact on their position: (1) perceptual saliency (or perceptual ease) includes such features as the morpheme position in the sentence, as well as the presence of affixes, stress and syllable; (2) frequency; (3) semantic complexity (e.g., spatial prepositions in, on, under may be easier than in front of, because it is easier to coordinate two points (location of $\mathrm{A}$ in relation to $\mathrm{B}$ ) than three points (location of A, B and the speaker); (4) grammar complexity, which includes three constituents: (a) presence of redundancy (e.g. in the sentence She likes dancing the verb morpheme $-S$ is redundant because the subject clearly indicates the third person singular); (b) presence of allomorphism, e.g. morpheme -ing has one allomorph, and morpheme $-s$ - three; thus, according to this criterion, -ing should be acquired faster than $-s$; (c) paradigm regularity, e.g. open - opened should be acquired faster than break-broke. 
The research (see the review in [8]) into the way the child goes from the perception of a particular morpheme to the development of broad grammar categories may be summarised as follows.

The child starts with memorising a lexical unit (e.g. pens) as an indivisible whole. This unit is assorted to one of the categories, e.g. category 1 - words, category 2 - affixes, category 3 - bases. Later, because of the similar units (e.g., books, toys, balls) generalisation, the base pen is transferred to category 3 , and the affix $-s-$ to category 2 . In the process of this transfer, all kinds of errors might happen. For example, pen and pens may both be present in category 1, or after the form pen has been moved to category 3 , the form pens may remain in category 1 , and the form penses might occur. Such errors, however, are highly improbable due to the operation of the hypothetic affix check principle, which bans the establishment of a new category if a particular meaning is already present in another category.

Generalisation and overgeneralisation are the two major mechanisms in the acquisition of morphology. In essence, generalisation is the transfer of a specific rule to the whole class of objects based on the analysis of their features. The strengthening of connections between the categories contributes to the establishment of semantic and category network, which starts operating as soon as suitable objects turn up. It may result in overgeneralisation (give - gived, woman - womans etc.), which is observed at the final stages of acquisition and is usually a reliable sign that the rule of the particular morpheme use has already been acquired and just requires a certain fine-tuning. Thus, overgeneralisation is an indicator of the child's inner grammar system restructuring.

At this final stage, alongside with overgeneralisation, the processes of its restriction are also under way. The very possibility of overgeneralisation is linked to the dramatic growth of connections between the categories. The redundant connections cause overgeneralisation, while their fine-tuning restricts the latter. The final stage involves the correction of overgeneralisation based on the feedback from the language environment. Using the examples above, it may be assumed that the observation of language environment informs the child's cognitive organiser of the absence of forms gived and womans. Hence, it marks them as exceptions and transfers them into a separate category.

Thus, the acquisition of morphology in English as a native language 
is based onthe following principles. According to the principle of lexical acquisition, paradigmatic variants (e.g. pen, pens) are first memorized as holistic indivisible units, and only later the affix is separated from the base and both elements are distributed among the corresponding categories. Consistent with the principle of generalisation, the cognitive organiser, following the monotypic units (e.g. books, toys, balls) comparison, formulates a hypothetic rule related to the said units use in speech. In line with the principle of overgeneralisation, the cognitive organiser initially transfers the specific rule application to a wider range of objects than it actually involves. Then, based on the feedback from the language environment, it fine-tunes the rule and restructures the grammar mechanisms correspondingly. In keeping with the principle of uniqueness, the cognitive organiser blocks the possibility of creating a rule, which allows, for example, two plural forms of the same word (e.g. womans and women). The principle of uniqueness allows the use of only one of the forms, specifically the one observed in the language environment [8: 66].

The operation of the said principles in the acquisition of English as a foreign language could be regarded as a proof of the NLA and FLA similarity, which is a prospect of our further research.

\section{LITERATURE}

1. Черноватый Л.Н. Основы теории педагогической грамматики иностранного языка: дис. ... д-ра пед. наук: 13.00.02 / Харьковский нац. ун-т им. В.Н.Каразина. Харьков, 1999. 453 с.

2. Berko J. The child's learning of English morphology. Word. 1958. № 14. P. $150-177$.

3. Brown R. A First Language: The Early Stages. Cambridge, Mass: Harvard Univ. Press, 1973. $430 \mathrm{p}$.

4. Chernovaty L.M. Pedagogical grammar as the framework of research in teaching foreign languages. Part 1. Levels and types of grammar. Викладання мов у вищих навчальних закладах освіти на сучасному етапі. Міжпредметні зв'язки. Х.: ХНУ ім. В.Н. Каразіна, 2016. Вип. 29. C. $157-166$.

5. Chernovaty L.M. Pedagogical grammar as the framework of research in teaching foreign languages. Part 2. Native language acquisition: General background. Викладання мов у вищих навчальних закладах освіти на сучасному етапі. Міжпредметні зв'язки. Х.: ХНУ ім. В.Н. Каразіна, 2017. Вип. 30. С. 156-65. 
6. Chernovaty L.M. Pedagogical grammar as the framework of TEFL research. Part 3. Native language acquisition: strategies, procedures and processes.Theword-combinationstage. Викладання мов у вищих навчальних закладах освіти на сучасному етапі. Міжпредметні зв'язки. Х.: ХНУ ім. В.Н. Каразіна, 2018. Вип. 31. С. 154-163.

7. Chernovaty L.M. Pedagogical grammar as the framework of TEFL research. Part 4. Foreign language acquisition: strategies, procedures and processes. Викладання мов у вищих навчальних закладах освіти на сучасному етапі. Міжпредметні зв'язки. Х.: ХНУ ім. В.Н. Каразіна, 2018. Вип. 32. C. $126-134$.

8. Ingram D. First Language Acquisition. Cambridge: Cambridge Univ.Press, $1992.572 \mathrm{p}$.

9. The Routledge Handbook of Second Language Acquisition / Gass S. M., Mackey A. (eds.). London: Routledge, 2012. 599 p.

10. White L. Second Language Acquisition and Universal Grammar. Cambridge: Cambridge University Press, 2003. 312 p.

\section{REFERENCES}

Berko, J. (1958). The child's learning of English morphology. Word. 14, pp. 150-177 [in English].

Brown, R. (1973). A First Language: The Early Stages. Cambridge, Mass: Harvard Univ. Press. [in English].

Chernovaty, L. (1999). Osnovy teorii pedagogicheskoi grammatiki inostrannogo yazyka [The Basics of the Foreign Language Pedagogical Grammar Theory]. Doctor of Sciences thesis. Kharkiv: V.N. Karazin Kharkiv National University [in Russian].

Chernovaty, L.M. (2016). Pedagogical grammar as the framework of research in teaching foreign languages. Part 1. Levels and types of grammar. Vykladannia mov u vyshchykh navchalnykh zakladakh osvity na suchasnomu etapi. Mizhpredmetni zviazky [Current teaching of languages at higher educational establishments. Interdisciplinary approach], 29, pp. 157-166 [in English].

Chernovaty, L.M. (2017). Pedagogical grammar as the framework of research in teaching foreign languages. Part 2. Native language acquisition: General background. Vykladannia mov u vyshchykh navchalnykh zakladakh osvity na suchasnomu etapi. Mizhpredmetni zviazky [Current teaching of languages at higher educational establishments. Interdisciplinary approach], 30, pp. 156-165 [in English].

Chernovaty, L.M. (2018). Pedagogical grammar as the framework of TEFL research. Part 3. Native language acquisition: strategies, procedures and processes.Theword-combinationstage. Vykladannia mov $u$ vyshchykh navchalnykh zakladakh osvity na suchasnomu etapi. Mizhpredmetni zviazky 
[Current teaching of languages at higher educational establishments. Interdisciplinary approach], 31, pp. 154-163 [in English].

Chernovaty, L.M. (2018). Pedagogical grammar as the framework of TEFL research. Part Foreign language acquisition: strategies, procedures and processes. Vykladannia mov u vyshchykh navchalnykh zakladakh osvity na suchasnomu etapi. Mizhpredmetni zviazky [Current teaching of languages at higher educational establishments. Interdisciplinary approach], 32, pp. 126-134 [in English].

Gass, S.M. and Mackey, A (Eds.). (2012). The Routledge Handbook of Second Language Acquisition. London: Routledge [in English].

Ingram, D. (1992). First Language Acquisition. Cambridge: Cambridge Univ. Press [in English].

White, L. (2003). Second Language Acquisition and Universal Grammar. Cambridge: Cambridge University Press [in English].

Стаття надійшла до редакиії: 17.09.2018

Черноватий Леонід Миколайович, докт. пед. наук, проф. кафедри перекладознавства імені Миколи Лукаша факультету іноземних мов Харківського національного університету імені В.Н. Каразіна (61022, Харків, майдан Свободи, 4); e-mail: leonid.chernovaty@karazin.ua; orcid: http://orcid.org/0000-0003-3411-9408.

Черноватый Леонид Николаевич, докт. пед. наук, проф. кафедры переводоведения имени Николая Лукаша факультета иностранных языков Харьковского национального университета имени В.Н. Каразина (61022, Харьков, площадь Свободы, 4); e-mail: leonid.chernovaty@karazin.ua; orcid: http://orcid.org/0000-0003-3411-9408.

Leonid Chernovaty, Doctor of Pedagogics, Professor, The School of Foreign Languages, The Department of English Translation Theory and Practice, V.N. Karazin Kharkiv National University (61022, Kharkiv, 4 Svoboda Square); e-mail: leonid.chernovaty@karazin.ua; orcid: http://orcid.org/0000-0003-34119408 . 